\title{
Contribution of toll-like receptor 9 gene single-nucleotide polymorphism to systemic lupus erythematosus
}

\author{
Piotr Piotrowski • Margarita Lianeri • \\ Mariusz Wudarski · Marzena Olesińska • \\ Paweł P. Jagodziński
}

Received: 1 February 2012/ Accepted: 23 August 2012/Published online: 5 September 2012

(C) The Author(s) 2012. This article is published with open access at Springerlink.com

\begin{abstract}
There are several studies on the association of TLR9 polymorphisms with systemic lupus erythematosus (SLE) in different ethnicities; however, the results are inconsistent. Therefore, we studied the distribution of the TLR9 $C>T$ (rs352140) polymorphism in patients with SLE $(n=254)$ and controls $(n=521)$ in a Polish population. We did not observe significant differences in the prevalence of the TLR $C>T$ genotype and alleles between patients with SLE and controls. However, we found a contribution of the T/T and T/C genotypes to renal $[\mathrm{OR}=2.949 \quad(95 \% \quad \mathrm{CI}=1.523-5.711, \quad p=0.001)$, $\left.\left(p_{\text {corr }}=0.017\right)\right]$ and immunologic disorders $[\mathrm{OR}=2.938$ (95\% CI $\left.1.500-5.755, p=0.0012),\left(p_{\text {corr }}=0.0204\right)\right]$ in SLE patients. Moreover, we observed a significant association between the TLR $9 \mathrm{~T} / \mathrm{T}$ and $\mathrm{T} / \mathrm{C}$ genotypes and the presence of anti-dsDNA Ab [OR $=3.682$ (1.647-8.230, $\left.p=0.001),\left(p_{\text {corr }}=0.017\right)\right]$. Our studies suggest that the $T L R 9 C>T$ (rs352140) polymorphism might contribute to renal and immunologic disorders and to the presence of anti-dsDNA Ab.
\end{abstract}

Keywords TLR9 $\cdot$ Polymorphisms $\cdot$ SLE

P. Piotrowski · M. Lianeri · P. P. Jagodziński ( $₫)$

Department of Biochemistry and Molecular Biology,

Poznań University of Medical Sciences, 6 Święcickiego St.,

60-781 Poznan, Poland

e-mail: pjagodzi@am.poznan.pl

M. Wudarski · M. Olesińska

Institute of Rheumatology, Warsaw, Poland

\section{Introduction}

Systemic lupus erythematosus (SLE) is a progressive and chronic autoimmune disorder in which the immune system cannot distinguish between the body's own tissues and foreign antigens, producing antibodies $(\mathrm{Ab})$ to self-antigens [1]. Flare-ups of SLE can be initiated by disparate environmental factors, such as exposure to ultraviolet light, drugs, chemicals, as well as viral and bacterial infections $[2,3]$. The underlying cause of SLE is elusive; however, it is well established that both environmental and genetic factors are involved in this disease [3-7]. Genome-wide association studies have revealed many SLE prone genes and the contribution of some of these genes to the risk of SLE have been studied in different ethnicities [7]. One of these genes is the toll-like receptor 9 (TLR9) gene located in susceptibility regions for SLE [7].

TLR9 plays an elementary role in pathogen recognition and activation of innate immunity [8-10]. This receptor recognizes unmethylated cytosine-phosphate-guanine $(\mathrm{CpG})$ dinucleotide motifs located in bacterial, viral and fungal DNA [8-12]. The TLR9 gene is expressed in macrophages and dendritic cells, and TLR9 has been shown to be present almost exclusively in endosomes [8, 13-15].

It has been demonstrated that TLR9 is involved in the development of autoimmunity in SLE patients [16-18]. Stimulation of TLR9 in the endosomes by host DNA leads to plasmacytoid dendritic cell activation and type I interferon biosynthesis, which is implicated in lupus pathophysiology [19]. TLR9 activation also promotes the production of $\operatorname{IgG} 2 \mathrm{a}$ and $\mathrm{IgG} 2 \mathrm{~b}$ autoantibodies recognizing host DNA, which further develop autoimmunity pathology [20]. The role of TLR9 in autoimmunity was also demonstrated by Leadbetter et al. [21], who indicated that DNA-containing complexes interacting with TLR9 may 
activate both autoreactive $\mathrm{B}$ cells and other antigen presenting cells.

There are several studies on the contribution of TLR9 polymorphisms to the risk of SLE in different ethnicities; however, the results are inconsistent [22-27]. The four TLR9 single-nucleotide polymorphisms rs187084, rs5743836, rs352139 and rs352140 in Caucasians are located in the same block of linkage disequilibrium (LD) HapMap CEU data (http://hapmap.ncbi.nlm.nih.gov/). Therefore, we aimed to study whether TLR9 C > T (rs352140) can be a genetic risk factor of SLE in the Polish population. Because SLE is a heterogeneous disorder, we also evaluated the contribution of this polymorphism to different clinical symptoms of SLE.

\section{Patients and methods}

Patients and controls

Data for two hundred and fifty-four women fulfilling the American College of Rheumatology Classification criteria for SLE [28, 29] were collected in a random manner for the study at the Institute of Rheumatology in Warsaw, Poland. Controls included five hundred and twenty-one unrelated healthy volunteers and healthy women selected during medical examination at the Institute of Mother and Child, Warsaw. Women with SLE and controls were of Polish Caucasian origin and of a similar age. The mean age of SLE patients at diagnosis was $36 \pm 9$ years and of controls $35 \pm 8$ years. All participating subjects provided written consent. The study procedures were approved by the Local Ethical Committee of Poznan University of Medical Sciences.

\section{Genotyping}

DNA was isolated from peripheral leucocytes using a standard salting out procedure. Identification of the TLR9 $\mathrm{C}>\mathrm{T}$ (rs352140) polymorphic variant was performed by polymerase chain reaction-restriction fragment length polymorphism (PCR-RFLP). PCR was conducted employing primer pair 5' GCAGCACCCTCAACTTCACC 3'and 5' GGCTGTGGATGTTGTTGTGG $3^{\prime}$. The PCR-amplified fragments of TLR 9 that were $360 \mathrm{bp}$ in length were isolated and digested with the endonuclease BstUI (CG/CG) New England BioLabs (Ipswich, USA). The TLR $9 \mathrm{C}$ allele was cleaved into $227 \mathrm{bp}$ and $133 \mathrm{bp}$ fragments, whereas the TLR9 $\mathrm{T}$ allele remained uncut. DNA fragments were separated by electrophoresis on $3 \%$ agarose gel and visualized by ethidium bromide staining. The TLR9 $\mathrm{C}>\mathrm{T}$ polymorphism was confirmed by repeated PCR-RFLP. Moreover, the restriction analysis was confirmed by commercial sequencing analysis.
Statistical analysis

The distribution of genotypes in patients and controls was examined for deviation from Hardy-Weinberg equilibrium using exact and log likelihood ratio Chi-squared $\left(\chi^{2}\right)$ tests (http://ihg.gsf.de/cgi-bin/hw/hwa1.pl). The polymorphism was tested for association with SLE incidence using the $\chi^{2}$ test for trend $\left(p_{\text {trend }}\right)$. The $\chi^{2}$ test was employed to examine differences in genotypic and allelic distribution between patients and controls, and a $p$ value $<0.05$ was considered statistically significant. The odds ratio (OR) and $95 \%$ confidence intervals $(95 \% \mathrm{CI})$ were calculated. Contribution of the TLR $9 \mathrm{C}>\mathrm{T}$ polymorphism to clinical manifestations and the production of autoantibodies were determined by $\chi^{2}$ test. The Bonferroni correction for multiple comparisons was used and both $p$ values, before $(p)$ and after correction ( $\left.p_{\text {corr }}\right)$, were determined.

\section{Results}

Distribution of the TLR9 C $>\mathrm{T}$ (rs352140)

polymorphism in SLE patients and healthy individuals

Prevalence of the TLR9 $\mathrm{C}>\mathrm{T}$ genotypes did not exhibit significant deviation from Hardy-Weinberg equilibrium between patients and controls. We observed a similar frequency of the TLR9 T/T genotype in patients with SLE and healthy individuals, and OR for SLE patients with the T/T versus $\mathrm{T} / \mathrm{C}$ and $\mathrm{C} / \mathrm{C}$ genotypes was $1.079 \quad(95 \%$ $\mathrm{CI}=0.7592-1.534, p=0.6713$ ) (Table 1$)$. The frequency of the TLR9 T/T and C/T genotypes was not statistically increased in patients with SLE than in controls OR = 1.414 (95\% CI $=0.9847-2.029, p=0.0598$ ) (Table 1). We also observed a non-significant increase in the TLRO T allele in patients compared to healthy individuals $\mathrm{OR}=$ 1.164 (95\% CI $=0.9412-1.439, p=0.1610)$ (Table 1). The $p$ value of the $\chi^{2}$ test of the trend observed for the TLR9 $C>T$ polymorphism was also not significant $\left(p_{\text {trend }}=0.1531\right)($ Table 1$)$.

Association of the TLR9 $\mathrm{C}>\mathrm{T}$ (rs352140) polymorphism with clinical manifestations and production of autoantibodies in patients with SLE.

We observed a contribution of the T/T and T/C genotypes to renal $\mathrm{OR}=2.949(95 \% \mathrm{CI}=1.523-5.711, p=0.001)$, $\left(p_{\text {corr }}=0.017\right)$ and immunologic disorders $\mathrm{OR}=2.938$ (95\% CI 1.500-5.755, $p=0.0012),\left(p_{\text {corr }}=0.0204\right)$ in SLE patients (Table 2). Moreover, we observed a significant association between the TLR $9 \mathrm{~T} / \mathrm{T}$ and T/C genotypes and the presence of anti-dsDNA Ab OR = $3.682(1.647-8.230$, $p=0.001),\left(p_{\text {corr }}=0.017\right)($ Table 3$)$. 
Table 1 Prevalence of the TLR9 $C>T$ (rs352140) polymorphism in SLE patients and controls

\begin{tabular}{lccccc}
\hline$T L R 9 C>T(r s 352140)$ & SLE $n=254$ & Controls $n=521$ & OR & $95 \%$ CI & $p$ value $p^{\mathrm{d}}$ \\
\hline Genotype frequency & $52(0.21)$ & $139(0.27)$ & & \\
C/C & $140(0.55)$ & $262(0.50)$ & & & \\
C/T & $62(0.24)$ & $120(0.23)$ & 1531 \\
T/T & $202(0.79)$ & $382(0.73)$ & $1.079^{\mathrm{a}}$ & $(0.7592-1.534)^{\mathrm{a}}$ & $0.6713^{\mathrm{a}}$ \\
C/T $+\mathrm{T} / \mathrm{T}$ & & & & $(0.9847-2.029)^{\mathrm{b}}$ & $0.0598^{\mathrm{b}}$ \\
Minor allele frequency & 0.52 & 0.48 & $1.164^{\mathrm{c}}$ & $0.9412-1.439^{\mathrm{c}}$ & $0.1610^{\mathrm{c}}$ \\
$\mathrm{T}$ & & & \\
\hline
\end{tabular}

The odds ratio (OR) was calculated for patients

a (T/T vs $\mathrm{C} / \mathrm{T}$ and $\mathrm{C} / \mathrm{C}$ genotype), ${ }^{\mathrm{b}}$ (T/T and $\mathrm{C} / \mathrm{T}$ vs $\mathrm{C} / \mathrm{C}$ genotype). We also determined the OR for the patients' minor allele; ${ }^{\mathrm{c}}$ ( $\mathrm{T}$ allele vs $\mathrm{C}$ allele); ${ }^{\mathrm{d}} \chi^{2}$ test

Table 2 Distribution of the TLR9 C > T (rs352140) polymorphism among SLE patients with different clinical manifestations

${ }^{a}$ Represents the absolute number of positive patients for $\mathrm{C} / \mathrm{C}, \mathrm{C} / \mathrm{T}$ and $\mathrm{T} / \mathrm{T}$ genotypes, respectively. Comparison of genotypes ${ }^{\mathrm{b}}$ ( $\mathrm{T} / \mathrm{T}$ or $\mathrm{C} / \mathrm{T}$ vs $\mathrm{C} / \mathrm{C}$ genotype) between patients with and patients without a particular manifestation was performed by ${ }^{c} \chi^{2}$ test. ${ }^{\mathrm{d}}$ Include presence of anti-DNA $\mathrm{Ab}$ or anti-Smith $\mathrm{Ab}$ or antiphospholipid $\mathrm{Ab}$

\begin{tabular}{lllll}
\hline Characteristic & \multicolumn{2}{l}{ Genotype distribution } & Odds ratio $(95 \% \mathrm{CI}), p^{\mathrm{c}}$ \\
\cline { 2 - 4 } & $\mathrm{C} / \mathrm{C}(52)^{\mathrm{a}}$ & $\mathrm{C} / \mathrm{T}(140)^{\mathrm{a}}$ & $\mathrm{T} / \mathrm{T}(62)^{\mathrm{a}}$ & \\
\hline Malar rash & 29 & 77 & 33 & \\
Discoid rash & 16 & 43 & 18 & \\
Phototosensitivity & 26 & 64 & 28 & \\
Oral or nasopharyngeal & 23 & 53 & 26 & \\
Arthritis & 14 & 33 & 15 & $2.949(1.523-5.711, p=0.001)^{\mathrm{b}}$ \\
Serositis & 10 & 25 & 11 & \\
Renal & 15 & 76 & 34 & $2.938(1.500-5.755, p=0.0012)^{\mathrm{b}}$ \\
Neurologic & 12 & 27 & 13 & \\
Hematologic & 19 & 47 & 21 & \\
Immunologic & & 76 & 29 & \\
ANA & 14 & 140 & 62 & \\
\hline
\end{tabular}

\section{Discussion}

Some studies have demonstrated increased TLR 9 expression in B cells from patients with SLE [30, 31]. Papadimitraki et al. [30] reported an increased proportion of peripheral blood memory $\mathrm{B}$ cells and plasma cells expressing TLR9, which correlated with the presence of anti-dsDNA Ab in patients with active SLE. Another study revealed that the level of TLR9 mRNA in B cells was increased in SLE patients, and TLR9 expression on CD20 ${ }^{+}$ B cells correlated with SLE activity and CH50 [31]. This may suggest that genetic variations of TLR 9 that affect their expression may have an effect on SLE development and clinical manifestation of this disease.

We did not observe a contribution of the TLR $9 \mathrm{C}>\mathrm{T}$ (rs352140) polymorphism to the risk of SLE in a Polish population. Recent studies conducted by Huang et al. (2011) suggested that the TLR9 -1486 T/C (rs187084) polymorphism, located in the LD block with rs352140, is related to SLE in Taiwanese patients. [22]. In addition to this finding, $\mathrm{Xu}$ et al. [23] demonstrated a significant association of rs352140 gene variants with the susceptibility to SLE in a Chinese population. Additionally, the TLR9 $\mathrm{G}$ allele at position +1174 of TLR9 (rs352139) conferred an increased risk for SLE in a Japanese population [24]. The contributions of rs5743836 to SLE have been observed in individuals of European descent from Southern Brazil; however, this was not confirmed in Caucasian American individuals [25, 32]. TLR9 polymorphisms were not significantly associated with the susceptibility to SLE and related phenotypes in Korean patients with SLE [26]. Furthermore, Zhou et al. [27] did not find a significant contribution of the rs 352140 polymorphism to SLE development in a Chinese Han population.

In our study, the TRL9 T/T and T/C genotypes exhibited a significantly increased risk of developing renal disease in patients with SLE. The significant association between the rs352140 gene variant and lupus nephritis was also observed in a Chinese Han population [27]. We also observed that the TRL9 T/T and T/C genotypes were significantly associated with immunologic disorders and the 
Table 3 Effect of the TLR9 C > T (rs352140) polymorphism on the presence of various autoantibodies in patients with SLE

\begin{tabular}{lcccc}
\hline Autoantibodies & \multicolumn{2}{l}{ Genotype distribution } & & Odds ratio (95 \% CI), $p^{\mathrm{c}}$ \\
\cline { 2 - 5 } & $\mathrm{C} / \mathrm{C}(52)^{\mathrm{a}}$ & $\mathrm{T} / \mathrm{C}(140)^{\mathrm{a}}$ & $\mathrm{T} / \mathrm{T}(62)^{\mathrm{a}}$ & $3.682(1.647-8.230$, \\
Anti-dsDNA & 8 & 58 & 23 & $0.001)^{\mathrm{b}}$ \\
Anti-Smith & 4 & & 6 & 13 \\
Anti-snRNP & 10 & 13 & 11 & 8 \\
Anti-Ro & 9 & 28 & 12 \\
Anti-La & 8 & 24 & 20 & \\
Anti-Scl-70 & 10 & 27 & & \\
\hline
\end{tabular}

${ }^{\mathrm{a}}$ Represents the absolute number of positive patients for $\mathrm{C} / \mathrm{C}, \mathrm{C} / \mathrm{T}$ and $\mathrm{T} / \mathrm{T}$. Genotype comparison ${ }^{\mathrm{b}}$ (T/T and T/C vs $\mathrm{C} / \mathrm{C}$ genotype) between patients with and patients without an autoantibody was performed by ${ }^{\mathrm{c}} \chi^{2}$ test

presence of anti-dsDNA Ab in patients with SLE. To date, an increased frequency of the TRL9 rs5743836 C allele has been observed in patients of European descent from Southern Brazil bearing the Anti-SSa/Ro Ab [25].

These differences in the effect of the TRL9 polymorphisms on SLE development and clinical manifestations in various populations may be due to racial heterogeneity, the size of the studied groups, or population exposure to disparate environmental factors.

The function of +1174 G/A of TLR9 rs187084 located in the LD block with rs352140 has been studied by Tao et al. [24], who demonstrated that the $+1174 \mathrm{G}$ variant may down-regulate TLR 9 expression. Moreover, they indicated that TLR9 rs187084 may contribute to differences in the B cell response to autoantigens and the production of autoantibodies [24].

Recently, the role of TLR9 expression in the production of anti-dsDNA $\mathrm{Ab}$ was confirmed by Chen et al. [33], who performed knockdown of TLR9 by siRNA in B cells, resulting in a reduction of anti-dsDNA Ab levels and amelioration of the disease in SLE murine model. Recent studies also suggest that the changes in TLR 9 expression may have an effect on renal disease development in SLE [34, 35]. Machida et al. [34] demonstrated that injured podocytes express TLR 9 in active lupus nephrites accompanied by proteinuria and elevated anti-dsDNA $\mathrm{Ab}$. In addition to this finding, Anders et al. [35] revealed that activation of TLR9 by $\mathrm{CpG}$ oligonucleotides in MRL-Fas (lpr) mice induces anti-dsDNA Ab production and renal disease.

Our study may suggest that renal disease and immunologic disorders, along with the presence of anti-dsDNA Ab, in SLE patients may be associated with the TRL9 (rs352140) T gene variant. However, to confirm the role of the rs352140 polymorphism in SLE, this study should be replicated in a larger and independent cohort.

Acknowledgments This study was supported by grant No 502-0101124182-07474, Poznań University of Medical Sciences. The technical assistance of Ms. Monika Świerczewska is gratefully acknowledged.

Open Access This article is distributed under the terms of the Creative Commons Attribution License which permits any use, distribution, and reproduction in any medium, provided the original author(s) and the source are credited.

\section{References}

1. Sekigawa I, Naito T, Hira $K$, Mitsuishi $K$, Ogasawara $H$, Hashimoto H, Ogawa H (2004) Possible mechanisms of gender bias in SLE: a new hypothesis involving a comparison of SLE with atopy. Lupus 13:217-222

2. Sarzi-Puttini P, Atzeni F, Iaccarino L, Doria A (2005) Environment and systemic lupus erythematosus: an overview. Autoimmunity $38: 465-472$

3. Jönsen A, Bengtsson AA, Nived O, Truedsson L, Sturfelt G (2007) Gene-environment interactions in the aetiology of systemic lupus erythematosus. Autoimmunity 40:613-617

4. Wong M, Tsao BP (2006) Current topics in human SLE genetics. Springer Semin Immunopathol 28:97-107

5. Hom G, Graham RR, Modrek B, Taylor KE, Ortmann W, Garnier S, Lee AT et al (2008) Association of systemiclupuserythematosus with C8orf13-BLK and ITGAM-ITGAX. N Engl J Med 358: 900-909

6. Warchoł T, Lianeri M, Łacki JK, Jagodziński PP (2010) SDF1-3' G801A polymorphisms in Polish patients with systemic lupus erythematosus. Mol Biol Rep 37:3121-3125

7. Harley IT, Kaufman KM, Langefeld CD, Harley JB, Kelly JA (2009) Genetic susceptibility to SLE: new insights from fine mapping and genome-wide association studies. Nat Rev Genet $10: 285-290$

8. Ahmad-Nejad P, Häcker H, Rutz M, Bauer S, Vabulas RM, Wagner H (2002) Bacterial CpG-DNA and lipopolysaccharides activate Toll-like receptors at distinct cellular compartments. Eur J Immunol 32:1958-1968

9. Kaisho T, Akira S (2001) Toll-like receptors and their signaling mechanism in innate immunity. Acta Odontol Scand 59:124-130

10. Hemmi H, Takeuchi O, Kawai T, Kaisho T, Sato S, Sanjo H, Matsumoto $\mathrm{M}$ et al (2000) A Toll-like receptor recognizes bacterial DNA. Nature 408:740-745

11. Ramirez-Ortiz ZG, Specht CA, Wang JP, Lee CK, Bartholomeu DC, Gazzinelli RT, Levitz SM (2008) Toll-like receptor 
9-dependent immune activation by unmethylated $\mathrm{CpG}$ motifs in Aspergillus fumigatus DNA. Infect Immun 76:2123-2129

12. Vilaysane A, Muruve DA (2009) The innate immune response to DNA. Semin Immunol 21:208-214

13. Heil F, Ahmad-Nejad P, Hemmi H, Hochrein H, Ampenberger F, Gellert T, Dietrich H et al (2003) The Toll-like receptor 7 (TLR7)specific stimulus loxoribine uncovers a strong relationship within the TLR7, 8 and 9 subfamily. Eur J Immunol 33:2987-2997

14. Matsumoto M, Funami K, Tanabe M, Oshiumi H, Shingai M, Seto Y, Yamamoto A et al (2003) Subcellular localization of Toll-like receptor 3 in human dendritic cells. J Immunol 171:3154-3162

15. Latz E, Schoenemeyer A, Visintin A, Fitzgerald KA, Monks BG, Knetter CF, Lien E et al (2004) TLR9 signals after translocating from the ER to $\mathrm{CpG}$ DNA in the lysosome. Nat Immunol 5:190-198

16. Guiducci C, Gong M, Xu Z, Gill M, Chaussabel D, Meeker T, Chan JH et al (2010) TLR recognition of self nucleic acids hampers glucocorticoid activity in lupus. Nature 465:937-941

17. Lafyatis R, Marshak-Rothstein A (2007) Toll-like receptors and innate immune responses in systemic lupus erythematosus. Arthritis Res Ther 9:222

18. Krieg AM, Vollmer J (2007) Toll-like receptors 7, 8, and 9: linking innate immunity to autoimmunity. Immunol Rev 220:251-269

19. Lande R, Gregorio J, Facchinetti V, Chatterjee B, Wang YH, Homey B, Cao W et al (2007) Plasmacytoid dendritic cells sense self-DNA coupled with antimicrobial peptide. Nature 449:564-569

20. Ehlers M, Fukuyama H, McGaha TL, Aderem A, Ravetch JV (2006) TLR9/MyD88 signaling is required for class switching to pathogenic $\operatorname{IgG} 2 \mathrm{a}$ and $2 \mathrm{~b}$ autoantibodies in SLE. J Exp Med 203:553-561

21. Leadbetter EA, Rifkin IR, Hohlbaum AM, Beaudette BC, Shlomchik MJ, Marshak-Rothstein A (2002) Chromatin-IgG complexes activate B cells by dual engagement of IgM and Tolllike receptors. Nature 416:603-607

22. Huang CM, Huang PH, Chen CL, Lin YJ, Tsai CH, Huang WL, Tsai FJ (2011) Association of toll-like receptor 9 gene polymorphism in Chinese patients with systemic lupus erythematosus in Taiwan. Rheumatol Int. doi:10.1007/s00296-011-1925-8

23. Xu CJ, Zhang WH, Pan HF, Li XP, Xu JH, Ye DQ (2009) Association study of a single nucleotide polymorphism in the exon 2 region of toll-like receptor 9 (TLR9) gene with susceptibility to systemic lupus erythematosus among Chinese. Mol Biol Rep 36:2245-2248

24. Tao K, Fujii M, Tsukumo S, Maekawa Y, Kishihara K, Kimoto Y, Horiuchi T et al (2007) Genetic variations of Toll-like receptor 9 predispose to systemic lupus erythematosus in Japanese population. Ann Rheum Dis 66:905-909

25. Dos Santos BP, Valverde JV, Rohr P, Monticielo OA, Brenol JC, Xavier RM, Chies JA (2011) TLR7/8/9 polymorphisms and their associations in systemic lupus erythematosus patients from Southern Brazil, Lupus. doi:10.1177/0961203311425522

26. Hur JW, Shin HD, Park BL, Kim LH, Kim SY, Bae SC (2005) Association study of Toll-like receptor 9 gene polymorphism in Korean patients with systemic lupus erythematosus. Tissue Antigens 65:266-270

27. Zhou XJ, Lv JC, Cheng WR, Yu L, Zhao MH, Zhang H (2010) Association of TLR9 gene polymorphisms with lupus nephritis in a Chinese Han population. Clin Exp Rheumatol 28:397-400

28. Tan EM, Cohen AS, Fries JF, Masi AT, McShane DJ, Rothfield NF, Schaller JG et al (1982) The 1982 revised criteria for the classification of systemic lupus erythematosus. Arthritis Rheum 25:1271-1277

29. Hochberg MC (1997) Updating the American College of Rheumatology revised criteria for the classification of systemic lupus erythematosus. Arthritis Rheum 40:1725

30. Papadimitraki ED, Choulaki C, Koutala E, Bertsias G, Tsatsanis C, Gergianaki I, Raptopoulou A et al (2006) Expansion of tolllike receptor 9-expressing B cells in active systemic lupus erythematosus: implications for the induction and maintenance of the autoimmune process. ArthritisRheum 54:3601-3611

31. Nakano S, Morimoto S, Suzuki J, Nozawa K, Amano H, Tokano Y, Takasaki Y (2008) Role of pathogenic auto-antibody production by Toll-like receptor 9 of B cells in active systemic lupus erythematosus. Rheumatology (Oxford) 47:145-149

32. Demirci FY, Manzi S, Ramsey-Goldman R, Kenney M, Shaw PS, Dunlop-Thomas CM, Kao AH et al (2007) Association study of Toll-like receptor 5 (TLR5) and Toll-like receptor 9 (TLR9) polymorphisms in systemic lupus erythematosus. J Rheumatol 34:1708-1711

33. Chen M, Zhang W, Xu W, Zhang F, Xiong S (2011) Blockade of TLR9 signaling in B cells impaired anti-dsDNA antibody production in mice induced by activated syngenic lymphocytederived DNA immunization. Mol Immunol 48:1532-1539

34. Machida H, Ito S, Hirose T, Takeshita F, Oshiro H, Nakamura T, Mori $\mathrm{M}$ et al (2010) Expression of Toll-like receptor 9 in renal podocytes in childhood-onset active and inactive lupus nephritis. Nephrol Dial Transplant 25:2530-2537

35. Anders HJ, Vielhauer V, Eis V, Linde Y, Kretzler M, Perez de Lema G, Strutz F et al (2004) Activation of toll-like receptor-9 induces progression of renal disease in MRL-Fas(lpr) mice. FASEB J 18:534-536 